忘がどのように進展するかを明らかにする方法の一つと して, 種々の電気量の充電または放電を行なった各䉓電 池を解体して，陽極板を一枚ずっとり出し，この極板の 各部分の活物質の $\mathrm{PbO}_{2}$ および $\mathrm{PbSO}_{4}$ を化学分析によ って定量した.

1. $3 \mathrm{~A}, 10 \mathrm{~A}, 20 \mathrm{~A}, 60 \mathrm{~A}$ で端子電压がそれぞれ 1.0 $\mathrm{V}$ および $150 \mathrm{~A}$ で $0.8 \mathrm{~V}$ まで放電した結果，活物質 $\mathrm{PbO}_{2}$ の $\mathrm{PbSO}_{4}$ への軽化率注放電電流の小さいほど増 加した.

2. 充管時には極板の上部から下部に向って，また放 電時には極板の下部から上部に向って活物質の反応は進 展する。

3.この蓄電池に使用されている陽極板 1 枚, 陰極板 2 枚を用いて，大量の電解液中で電池を構成した場合,
活物質の反応進展模様は極板がコンパクトに充てんされ た場合と同じ傾向であるが，それほど顕著でなかった。

4.これらの結果は, 極板の色調変化の肉眼的観察結 果ともよく対応した。

(昭 41-9-3 受瑟)

\section{文献}

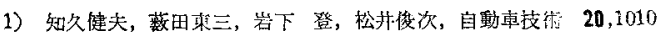
(1966).

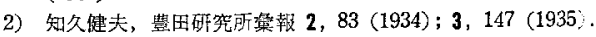

3）知久健夫, 豊田研究所異報 6, 15 (1939).

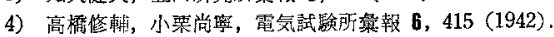

5）洼川真男，GS Neres 21，9（1951）。

6) A.C. Simon, E.L. Jones, J. Electrochem. Soc. 109, 760 (1962).

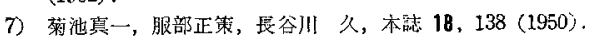

8) 知久健夫, 二宫 清, C.I.T.C.E. 17 th meeting(1966), Japan.

9）高木誠司，“定量分析の実駼之計算” 2, p. 371 (1964)，共立出原。

10）平野四蔵，“工業分析化学実験下” p. 432 (1965), 共江出原.

\title{
イオン交換膜を用いた $[\mathrm{Na} \cdot \mathrm{Hg} / \mathrm{NaOH}-\mathrm{HCl} / \mathrm{Pt}]$ 系電池の特性に関する研究* \\ Studies on the Characteristics of the Cell $(\mathrm{Na} \cdot \mathrm{Hg} / \mathrm{NaOH}-\mathrm{HCl} / \mathrm{Pt})$ Using Ion-Exchange Membranes
}

\author{
尾上秀夫**, 松野 武 雄** \\ Hideo Onoue, Takeo Matsuno
}

\section{1 緒 言}

著者ら江すでにイオン交換膜を用いる食塩水の浱淡電 池”およびナトリウム・アマルガム/食塩水の負極と塩酸 加の水素発生の白金正極とをイオン交換膜を用いて組 文合わせた電池 ${ }^{2), 3)}$ の諸特性について報告した。

本報で注なるべく起雪力が大きく，しかも问時化純度 の高いカセイソーダをらることのできる電池を組み立て た。すな和ち負極としてナトリウム・アマルガム/カセ インーダ溶液, 陰イオン交換膜を隔てて水酸化カルシウ 么飽和溶液を中室液とし，さらに陽イオン交換膜を隔て

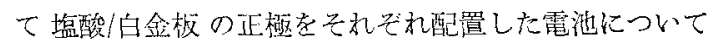
調ベることにした。

本報の電池も前報2)と同樣江正極系として承素発生に 有利な酸を用いているので, 従来のカセイソーダ溶液か ら水素発生を行ならいわ叻る“解口ウ電池”よりも起電 カが相当大きくなる．しかも純度の高いカセイソーダを 能率よく同時にうることを目的として，負極液に力七イ ソーダ溶液を用い，陰イオンとして水酸イオンのみをも つ中室液とを陰イオン交換膜を用いて組み合すせたので

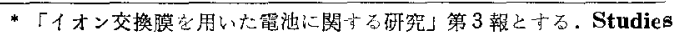
on the Cell Using the Ion-Exchange Membrane (Part 3) 電気化学協会第 33 回大会 (東京) にて一部発表

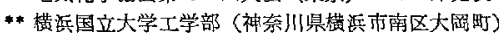

ある。

正極液は廃酸利用も考慮して希薄な湦度 $(0.1 \sim 1 N)$ を対象とし，一方負極液の力七イソーダ溶液法 $3 \sim 5 N$ を採用した。

\section{2 実 験 方 法}

\section{1 試料}

イオン交換膜は，旭ガラス (株) 製の陽イオン交掺膜 CMG-10 および陰イオン交換膜 $\mathrm{AMG}-10$ 学乵”同 様の処理在して用いた．正極は平滑白金板の場合，蒸留 水で洗ってから用いようとする濃度の塩酸に 1 時閒以上 ひたしてから使用しまたチタン白金メッキ板の場合に は, チタン板を硫酸で前処理後, D.N.S. 浴を用いて全 波整流の直流でメッキした電極 ${ }^{4}$ を十分水洗し，志らに 使用する正極液で洗浄してから用いた，負極は前報”上 同核に電解法で作ったもの衣用い，電解液はすべて市敗 特級試薬より調整した。

\section{2 電池の構造}

本研究に用いた電池は三室型であり，その断面圆高脳 1 に示す.

イオン交換膜（厚さ $0.2 \mathrm{~m} / \mathrm{m}$ ) の有効表面積は 1.54 $\mathrm{cm}^{2}$ で，負極と負極液との閒にはテトロン布(画積 1.54 $\left.\mathrm{cm}^{2}\right)$ を張る. 正極の大きさは $3.7 \times 4.7 \times 0.02(\mathrm{~cm}) て ゙$ 


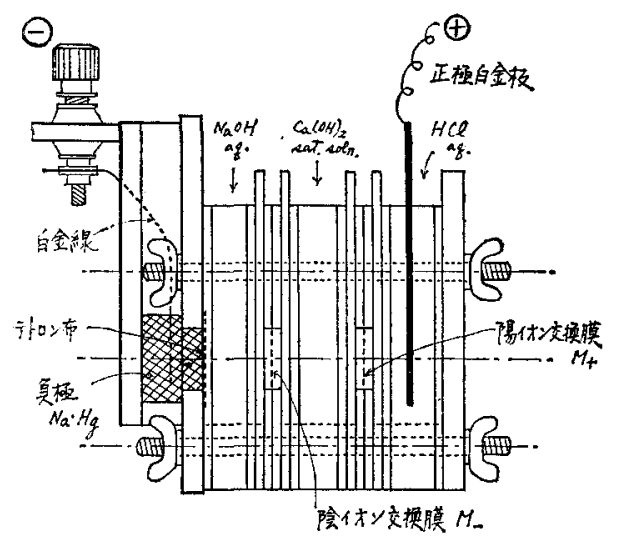

図1霔池の構造

ある。

鱼極公には 3〜5Nのカ七イソーダ水溶液, 中室には 水酸化カルシウム飽和水溶液, 正極室には $0.1 \sim 1 N$ 塩 酸水溶液汃それぞれ入っている。

\section{3 起電力の測定と定電流放電試験}

図1亿示した電池を使用し，はじめにアマルガムを入 れないで, 正極液, 負極液および中室液を入れて, 約 10 時間放置する、測定開始直前にこれらの電解液を外にあ け，アアルガムを貧極室に入れてから新しい電解液をそ れそれ大れ，正極を入れて直ちに雨極間の電位差を Heathkit D真空管式電在計（IM-II 型）を用いて测定 した.

つぎに電池の両極に直列に可変抵抗器执よび直流電流 計さつなぎ一定電流で放電させ，放電中の雨極間の電圧 を新記真空管式電圧計で測定した。

\section{4 放電時における各部電圧降下の測定}

つぎに放電時の各部の電在降下を測定した。測定方法

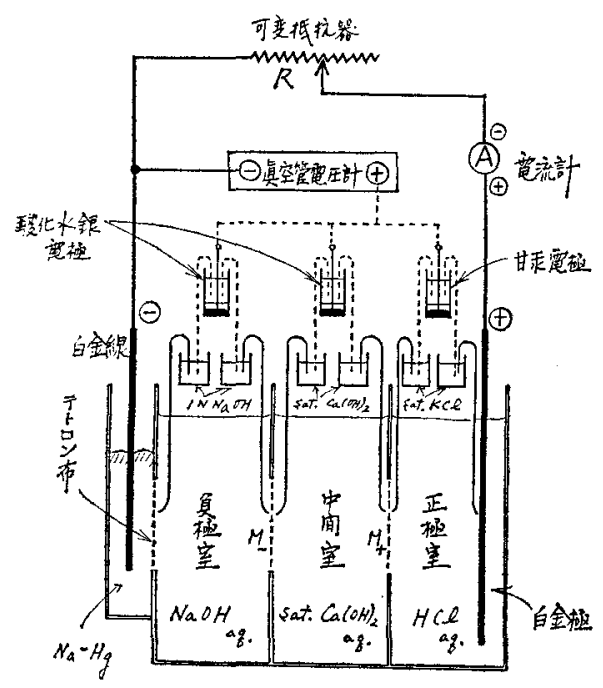

図 2 電池各部の分極測定回路
は前報 ${ }^{2)}$ とほぼ同様で，図1に示した電池を 2.3 と同様 にセットし，さらに図 2 のごとく酸化水銀電極および甘 コウ電極からのチップを負極表面, 陰イオン交換膜およ び陽イオン交換膜の両側面, 正極表面にそれぞれできる だけ接近させて配置し，一定電流で放電させたときの相 隣る各電極チップ間の電位と, 放電 10 分後に電流を切 ったときのそれらの電位との差を求めて，それぞれ各部 の放電による電圧降下とした（電流密度はすべて膜面積 につマて計算した).

\section{3 結果と考察}

\section{1 起電力およひ定電流放電中の端子電厌変化}

負極が $0.4 \%$ ナトリウム・アマルガム, 負極液が $5 \mathrm{~N}$ カ七イソーダ溶液, 中室液が飽和水酸化カルシウム溶 液, 正極液が $1 N$ 塩酸溶液, 正極が平滑白金板の場合 の $15^{\circ} \mathrm{C}$ に扔ける起電力および $0.1,0.2,0.3,0.4,0.5$, $0.6\left(\mathrm{~A} / \mathrm{dm}^{2}\right)$ のそれぞれにおける定電流放電時の端子電 圧の経時変化を図 3 に示す。 寸なわら図 3 に扎て放電 時間 0 分のときの值が起電力である.

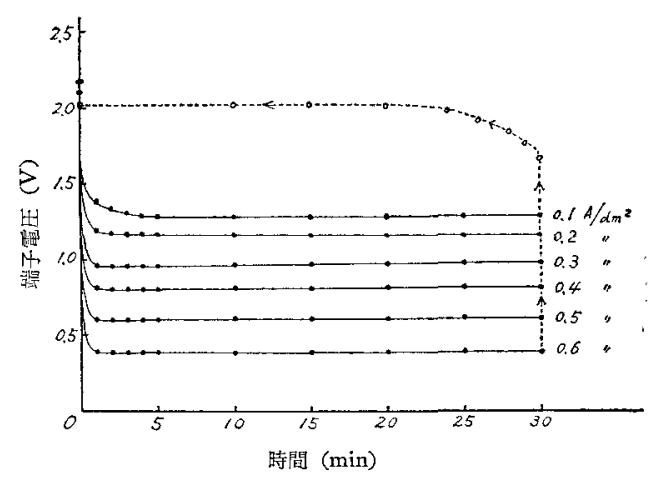

$\mathrm{NaOH}(5 N), \mathrm{Ca}(\mathrm{OH})_{2}$ (Sat.), $\mathrm{HCl}(1 N)$ 系

図 3 定電流放電特性

図3からわかるよらに起電力は多少のバラツキはある が，2.1〜2.2V の籁囲であった．このバラッキは後で 述べるよらに, 主として正極に打ける平衡電位のバラッ キに上るものと思われる。

放電すると端子電压は急激に下がるが，数分後からは 非常に安定し，ほとんど一定值を示すことがわかった。 放電による電佭下が大きいことから，この電池の内部 抵抗は相当に大きいことがわかる.また 30 分間放電し た後電流を切ると，端子電圧汪点線のごとくに回復して 10 分後には，放電時の電流のいかんにかか力らす，、 ずれも約 $2 \mathrm{~V}$ となった。この值電極表面状態および 電池各室の液濃度が，放電前と比較して多少異なるため 真の起電力よりは幾分低い值となっているのであろう.

\section{2 放電特性の測定}

次に負極液を $3 N$ カセイソーダ溶液にし, 正極液を それぞれ $0.1,0.5,1.0 \mathrm{~N}$ とし，種々の電流密度で放電 


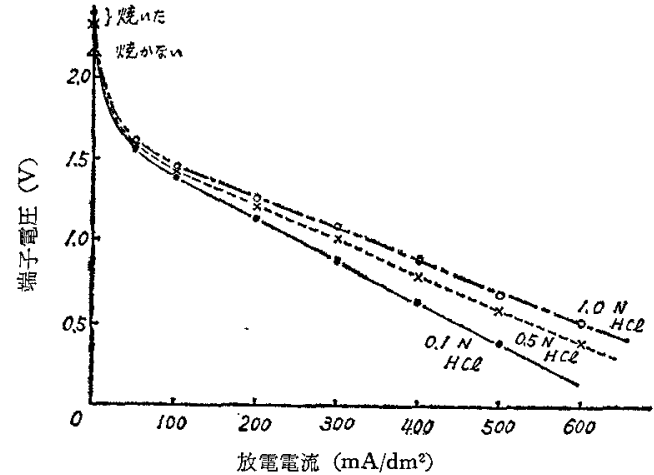

$\mathrm{NaOH}(3 N), \mathrm{Ca}(\mathrm{OH})_{2}($ Sat. $), \mathrm{HCl}(0.1 N, 0.5 N, 1.0 N)$ 系

图 4 放電特性に求上洼す正極液濃度の影響

させたときの放電開始 10 分後の端子電圧を放電電流の 関数として，それぞれ図4に示す.

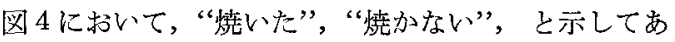
るが，前者は正極白金板を使用直前にガスバーナーの酸 化炎で十分に赤熱した後, 空気中に放置して冷却後電池 を組んで直らに测定した值で，一方“焼かない”という 方の值は，塩酸中で少なくとも 3 時間以上水素を発生さ せておいた電極を，赤熱処理をしないで空気中に放置し てから使用したときの起電力である, 図 4 に示すように 雨者のひらきが 200 300 mV あることがわかった. 起 電力が約 $2 \mathrm{~V}$ の電池で $200 \mathrm{mV}$ 以上の差の認められる ことは，このことたけから考えると電極の赤熱処理は非 常に有利なように思われる。

しかし放電すると“烍いた”電極の端子電压は “焼か ない”電極よりも急激に下がり, 30 分後には耐者の值は 全く一致してしまうことを認めた。そこで“焼いた”電 楆と“焼かない”電極とで㵊初その表面状態が異なる ため，異なる平衡電位を示し，“燒いた”電極の方が放 電初期では若十高い電極電位であるが, 次第に表面状態 が焼かない電極と同じような状態になってしまうのであ ろう。また白金電極の平衡電位が，その表面状態によっ てこれほど大きく樭なるといらことは，本報の電池の起 電力測定值が 3.1 に述べたごとく相当にバラックという ことの原因の一つとも考えられる.

図 4 に打いて, 正極液の塩酸濃度が $0.1 \mathrm{~N}, 0.5 \mathrm{~N}$, $1.0 \mathrm{~N}$ と高くなるにしたがい，この電池の放電特性が良 好になるのは当然であるが，相互の電圧降下分の差が相 当大きいといらことは，次項で述べるように，正極およ び正極液を含めた正極室全体の分極が相当大きいことを 示している．中た端子電压が電流密度の低いときは急激 に下がり，その後は放電電流の增加に従い，ほぼ直線的 に降下しているのは興味ある特性で，これらについては 3.3 において検討寸る。

また本報で考えている電池の中室液は原理的には陰イ オンとして水酸基をもつものならば混合液でもさしつか

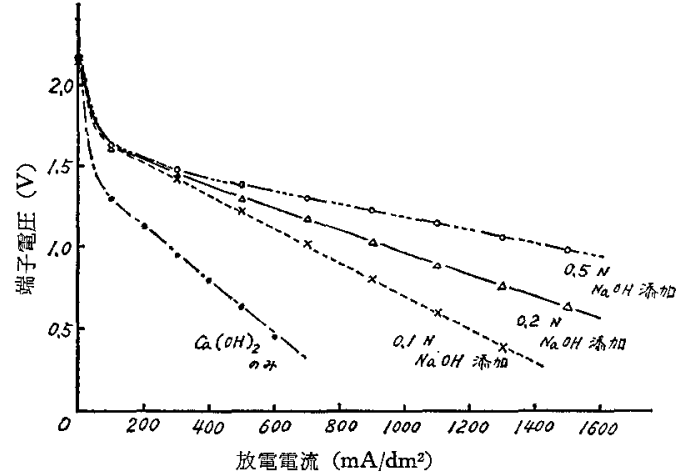

$\mathrm{NaOH}(5 N)\left\{\begin{array}{l}\mathrm{Ca}(\mathrm{OH})_{2}(\mathrm{Sat}) \\ \mathrm{Ca}(\mathrm{OH})_{2}(\mathrm{Sat})+(0.1 N, 0.2 N, 0.5 N)\end{array}\right\} \mathrm{HCl}(1 N)$

図 5 放電特性におよ济豆中間液中の $\mathrm{NaOH}$ 濃度の影響

えなくむしろ水酸イオンの全濃度が高くなれば，電導 度の関係でそれだけ放電特性注改善されるはずである。 そこで中空に水酸化カルシウム飽和溶液のみでなく，力 セイソーダを $0.1 \mathrm{~N}, 0.2 \mathrm{~N}, 0.5 \mathrm{~N}$ のそれぞれの濃度に なるように添加した. そのときの放電特性を図 5 に示 す.

図 5 を兄ると，カセイソーダの添加により，放電特性 が著しく改善されること，抏よび水酸化カルシウム飽和 溶液のみでは，中室液の電圧降下が非常に大きいことが わかった。

\section{3 放電時の各部の電压降下}

この電池の起電力は高いが放電時の電圧降下が相当に 大きいことがわかった. 3.2 に执いて正極系と中室液に おける分極の大きいことがほぼ推察されたが，この電池 が水溶液系の電池としては, 比較的複雑な構造をもつた め, 電池の各部分について, 電圧降下を前述の 2.4 の方 法によって測定した。

そこで，照合電極のチップを各部にそう入して放電中 および放電後の電位の差から各部の分極を求めた. 負極 液に $5 N$ カセイソーダ溶液, 中室液に水酸化カルシウ

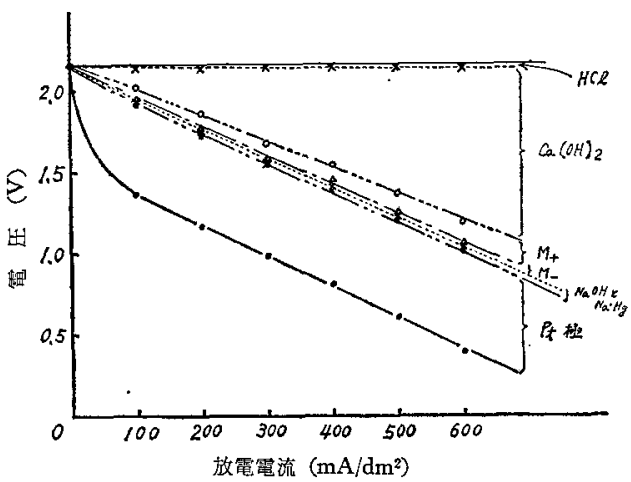

$\mathrm{NaOH}(5 \mathrm{~N}), \mathrm{Ca}(\mathrm{OH})_{2}$ (Sat.), $\mathrm{HCl}(1 \mathrm{~N})$ 采 (中室液中に $\mathrm{NaOH}$ を含を好場合)

図 6 各部の分極一電流曲線（その1） 
厶飽和溶液，正極液に $1 N$ 塩酸をそれぞれ用いたとき の各部の分極を放電電流の関数として図 6 に示す.

図 6 力ら正極以外の分極注大体オーム損的傾向定しし ているが，正極の分極だけは，電流密度の比較的小さい ところで電流密度の増加にともない急激な分極の増大が あり，その後はわずかずつ増大するという特性を示すこ とがわかった。

次に中室液での電圧降下が意外に大きく $500 \mathrm{~mA} / \mathrm{dm}^{2}$ 以上の電流密度で全体の約半分になるということがわか った。この結果は図 5 において中室液にカセイソーダを 添加したとき，電池の特性が著しく改善されたことによ って閒接的に証明されている.

中室液にカセイソーダを $0.1 \mathrm{~N}, 0.2 \mathrm{~N}$ および $0.5 \mathrm{~N}$ の濃度になるようにそれぞれ添加したときの各部の分極 を測定した．その例として，0.1 N NaOH の場合を図 7 に, $0.5 \mathrm{~N} \mathrm{NaOH}$ の場合を図 8 に，それぞれ電流密 度の関数として示す. 中室液に打ける電圧降下が力セイ ソーダの添加濃度が高いほど小さくなっていくのは当然 であるが，図6のカセイソーダを添加しない場合と比べ て，0.1Nの場合でも中室液の電圧降下が無添加のとき
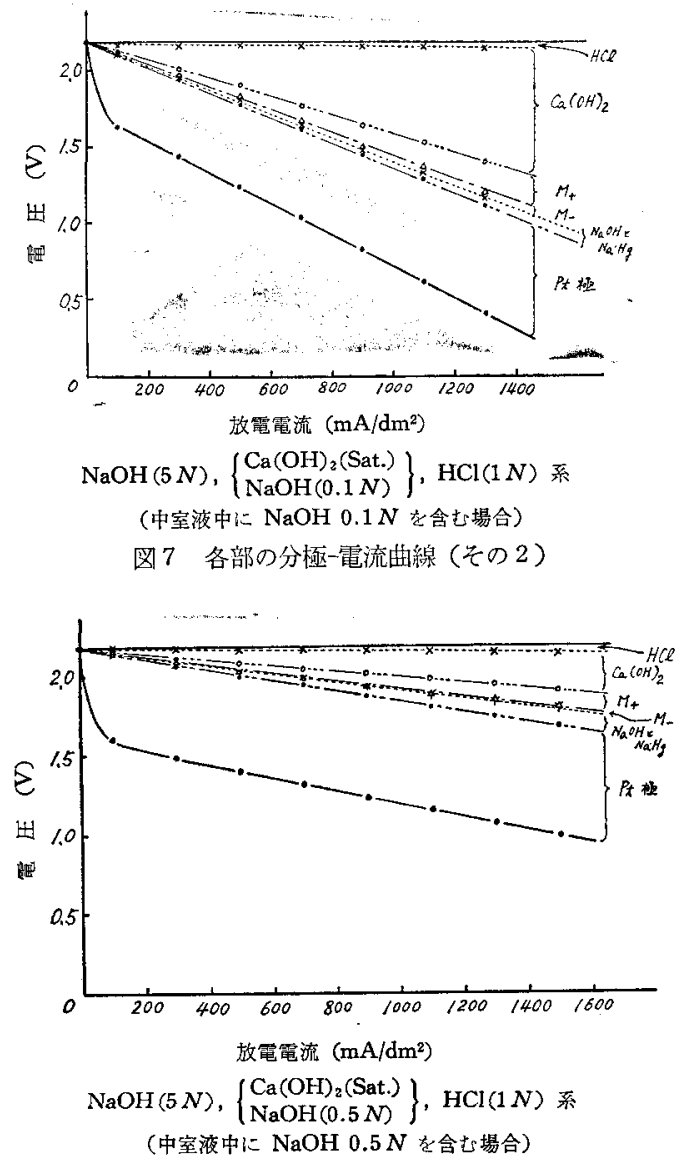

（中室液中に $\mathrm{NaOH} 0.5 N$ t含場合）

图 8 各部の分極一電流曲線（その 3 ）
とくらべて約 $1 / 3$ になっていることがわかっった。

陰陽両イオン交換膜の分極もカセイソーダの添加濃度 が高くなるに従い減少しているがここれ、これらのイ オン交換膜がいずれも片面が中室液に接しているため， イオン交換膜の電導度が增大したこと，拉よび膜面にお ける濃度分極が小さくなったことによると思われる。

しかし，いずれにせよ，雨イオン交換膜，正極液，焦 極液执よび負極での電圧降下は正極执よび中室液での電 圧降下に比べるとそれほど問題にはならないといえる。

したがって，この電池の特性改善には，二枚の膜の間げ きをせ汭ること，中室液の水酸イオンの濃度を高める こと，および正極についての検討が最も重要であると思 われる。

次に正極として平滑白金板のかわりに白金メッキチ夕 ン板を用いた場合の放電特性を求めた，チタン板に白金 メッキする場合，白金の厚さは“薄付け”チタン白金板 注約 $1 \mu$ で，メッキ後沈降性炭酸カルシウムで表面を軽 く摩き光沢がある。一方“愿付け”チタン白金板は上記 “薄付け”チタン白金板の上にさらに約 $1 \mu$ 白金メッキ してから再度沈降性炭酸カルシウムで摩いてからさらに

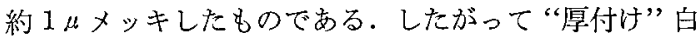
金メッキ板は合計約 $3 \mu$ の白金がついていることになり ，しかも最後のメッキ後は摩いてないので，表面は電着 面がそのまま出て㧍り灰色である。

放電特性の一例として，負極液 $5 N$ カセイソーダ溶 液, 中室液飽和水酸化カルシウム $+0.1 N$ カセイソーダ 溶液，正極液 $1 N$ 塩酸溶液，正極“薄付け”チタン当 金板をそれぞれ用いた場合の放電特性と電池内各部の分 極を図 9 に示す。

図9 と図 7 とを比較すると, 電池の起電力と正極以外 の部分の分極については相互にほとんど差が認められな いが，正極に抒ける分極は図 9 の“薄付け”チタン白金 板を用いた方が図70平滑白金板を用いたときより小さ くなっていることがわかる。

“厚付け”チタン白金板の分極を“薄付け”チタン白 金板および平滑白金板の分極と比較するため，電流密度

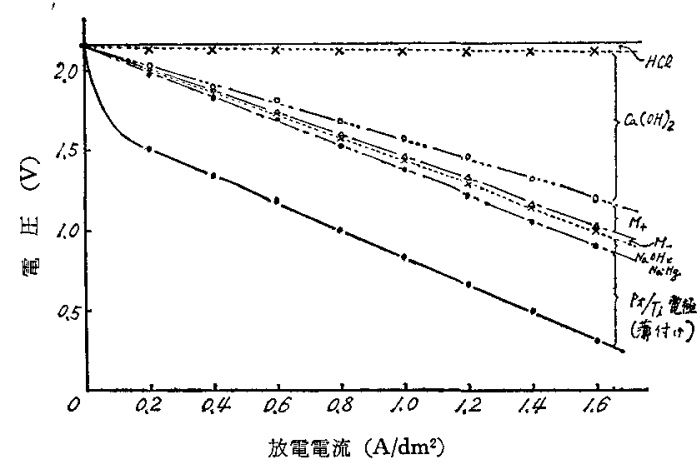

図 9 (薄付け) チタン白金電極を用いたときの放電特性 


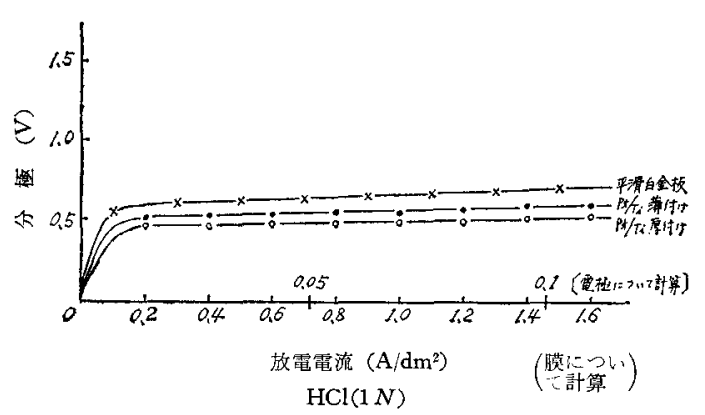

図 10 正極の分極一雪流曲線

の関数として図 10 にまとめて示す．横軸の電流密度の 目盛りのうち，上側に示したのは電極面積について計算 したもので，下側の目盛りは図 4 9 と同様に膜面積に 対する電流密度で示し，比較検討に便利なようにした．

図 10 を見ると，平滑白金板の分極が一番大きく，つ ぎがチタン白金薄付けメッキ板で，一番分極が小さいも のがチタン厚付け白金メッキ板となっている，そして三 者ともに測定時間中に分極值の変動はほとんど認められ なかった。しかも電極の分極曲線は皆同じような形をし て扣り，ただ大きさが異なっているだけである。そこで これらの電極は，ただ真の表面積のみがそれぞれ異なっ ているだけで蚛り，しかもこのような濃度の塩酸中で電 池の正極として使用しても，特に表面状態に変化はなく したがって一応このような使用条件に恃耐觉られるとい らことがわかった．使用後における電極表面の顕微鏡観 察でも，なんら変化は見られず，このよらな使用条件で は，本研究に用いた白金メッキチタン板が一応使用に耐 えるばかりでなく，真の表面積が大きいので，電極とし ての寿命を無視すれば，平滑白金板よりもむしろ有利で あるといえる。

厚付けメッキ板の方が分極特性が良いのは, 電着後白 金表面を摩かずに水洗しただけで使用したため，一度摩 いて光沢を出してから使用した薄付けメッキ板よりも真 の表面積が大きいことが相当有効传いているのである ら. 厚付けメッ手板は薄付けメッキ板よりる水素気ほう の付着が多加たが，肉眼的には非常に平らに見觉る平 滑白金板よりも気ほうの付着量はずっと少なかった。し たがって水素気ほうの付着は単に電極表面の幾何学的な あらさのみによるのではなく，むと複雑な界面の諸因 子の相互関係によるのであるう．したがって真の表面積 が非常に大きくて，しかも気ほ5の離脱のしやすいよう な白金表面を作ることも可能加も知れない。これらの点 については今後さらに検討したい。

\section{4 総 括}

負極としてナトリウム・アマルガム，負極液にカセイ ソーダ水溶液, 陰イオン交換膜を隔てて中室液に水酸化 カルシウム飽和水溶液（またはそれにさらにカセインー ダを添加した混合溶液),陽イオン交換膜を隔てて正極液 に塩酸，正極に白金板（または白金メッキチタン板）を それぞれ用いた電池を組み, 起電力, 放電特性执よび電 池内各部の電圧降下を測定した。

（1）この電溜の起電力は約 2.1 2.2V であった. 起電力測定值に多少バラッキがみられたのは, 主として 正極の表面状態の差異に基づく正極の平衡電位の差によ るものである。

（2）あらかじめ“焼いた”白金板を正極として用い ると，電池の起電力は $2.3 \mathrm{Vをこすほどになるが，この}$ 電極の活性化（電極がより貴な電位を示寸こと）は一時 的なもので，通常の電池の使用目的からは，この燒くと いら電極の前処理は急味のないことであった.

（3）放笔すると端子電圧隐に下がるが，数分間で ほとんど安定し，その後は平坦な放電特性を示した。 そ こで, 放電 10 分後の端子電圧をそれぞれの電流密度の 関数として, 種々の正極液湱度および中室液における種 々のカセイソーダ添加量について求めた.

(4) 放電 10 分後の電池内各部の電圧降下を電流密 度の関数であらわした，それによると，正極の分極およ び中室液での電圧降下が大きく，その他の部分の分極法 比較的小さいことがわかった。

（5）正極の分極は比較的電流密度の小さいところで は，電流密度の増大とともに急激に増すが，その後は電 流密度が增すにしたがって徐々に分極が増大寸る活性化 過電圧である.しかし正極以外の部分の電圧降下は電流 密度とともに大体值線的偪大寸るオーム損的なもので あることがわかった。

（6）中室液にカセイソーダを添加すると中室液にお ける電圧降下が大幅に減るので, 電池の放電特性が著し く改善された。

（7）正極に白金メッキチタン板を使用したところ， 実験の範囲内では，本報のような電池の正極としては十 分に使用に耐えるばかりでなく，平滑白金板よりも表面 積が大きく，乙かも水素気ほらの離脱が良いため，分極 特性が改善されることがわかった。

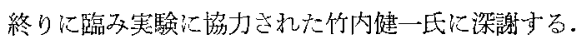

(昭 41-9-3 受理)

\section{文献}

1）松野武雄，尾上费夫，本誌 33，883 (1965)。

2）松野武雄，宒上秀夫，本㰴 34，413 (1966).

3）淞野武雄，尾上秀夫，特公昭 41-8415.

4）松野武雄，尾上秀夫，本誌 32，747 (1964). 